\title{
Association of the lipoprotein receptor-related protein 2 gene with gout and non-additive interaction with alcohol consumption
}

Humaira Rasheed ${ }^{1}$, Amanda Phipps-Green ${ }^{1}$, Ruth Topless' ${ }^{1}$, Jade E Hollis-Moffatt ${ }^{1}$, Jennie Harré Hindmarsh², Christopher Franklin ${ }^{3}$, Nicola Dalbeth ${ }^{3}$, Peter B Jones ${ }^{3}$, Douglas HN White ${ }^{4}$, Lisa K Stamp ${ }^{5}$ and Tony R Merriman ${ }^{1 *}$

\begin{abstract}
Introduction: The T allele of a single nucleotide polymorphism (SNP: rs2544390) in lipoprotein receptor-related protein 2 (LRP2) is associated with higher serum urate and risk of gout in Japanese individuals. SNP rs2544390 also interacts with alcohol consumption in determining hyperuricemia in this population. We investigated the association of rs 2544390 with gout, and interaction with all types of alcohol consumption in European and New Zealand (NZ) Māori and Pacific subjects, and a Māori study cohort from the East Coast region of NZ's North Island.

Methods: Rs 2544390 was genotyped by Taqman ${ }^{\circledast}$. From NZ a total of 1205 controls and 1431 gout cases clinically ascertained were used. Publicly available genotype and serum urate data were utilized from the Atherosclerosis Risk in Communities (ARIC) study and the Framingham Heart Study (FHS). Alcohol consumption data were obtained by consumption frequency questions in all study cohorts. Multivariate adjusted logistic regression was done using STATA.

Results: The T allele of rs 2544390 was associated with increased risk of gout in the combined Māori and Pacific Island cohort ( $\mathrm{OR}=1.20, P=0.009)$, and associated with gout in the European subjects, but with a protective effect $\left(\mathrm{OR}=0.79, P_{\text {Unadjusted }}=0.02\right)$. Alcohol consumption was positively associated with risk of gout in Māori and Pacific subjects $(0.2 \%$ increased risk $/ \mathrm{g} /$ week, $P=0.004)$. There was a non-additive interaction between any alcohol intake and the risk of gout in the combined Māori and Pacific cohorts $\left(P_{\text {Interaction }}=0.001\right)$, where any alcohol intake was associated with a 4.18-fold increased risk in the CC genotype group $\left(P=6.6 \times 10^{-5}\right)$, compared with a 1.14-fold increased risk in the $\mathrm{CT} / \mathrm{TT}$ genotype group $(P=0.40)$. These effects were not observed in European subjects.

Conclusions: Association of the T-allele with gout risk in the Māori and Pacific subjects was consistent with this allele increasing serum urate in Japanese individuals. The non-additive interaction in the Māori and Pacific subjects showed that alcohol consumption over-rides any protective effect conferred by the CC genotype. Further exploration of the mechanism underlying this interaction should generate new understanding of the biological role of alcohol in gout, in addition to strengthening the evidence base for reduction of alcohol consumption in the management of gout.
\end{abstract}

\section{Introduction}

Elevated serum urate in humans is the central risk factor for gout. To date genome-wide association scanning has identified 28 loci that explain approximately $6 \%$ of the variation in serum urate levels in European Caucasians [1]. Prominent associations are with renal (SLC2A9, SLC17A1, SLC22A11, SLC22A12, PDZK1) and gut $(A B C G 2)$ molecules directly involved in urate transport.

\footnotetext{
* Correspondence: tony.merriman@otago.ac.nz

${ }^{1}$ Department of Biochemistry, University of Otago, Dunedin, New Zealand Full list of author information is available at the end of the article
}

Not unexpectedly some of these genes are also associated with gout [1-4]. In Japanese the $T$ allele of single nucleotide polymorphism (SNP) rs 2544390 in the LRP2 gene has been associated with elevated serum urate by genomewide scanning [5] and is associated with gout in Japanese, conferring a moderate risk of odds ratio $(\mathrm{OR})=1.32$ [6]. LRP2, also known as megalin, is a member of the lipoprotein receptor-related protein (LRP) family, with its predominant function in lipid metabolism through controlling the activity of lipoprotein lipase [7,8]. LRP2 plays a role in the reabsorption and metabolism of renal

\section{Ciomed Central}

(c) 2013 Rasheed et al.; licensee BioMed Central Ltd. This is an open access article distributed under the terms of the Creative Commons Attribution License (http://creativecommons.org/licenses/by/2.0), which permits unrestricted use, distribution, and reproduction in any medium, provided the original work is properly cited. 
glomerular-filtered substances, including albumin and low molecular weight proteins [9].

Along with inherited genetic variants, dietary factors, such as sugar-sweetened beverages and alcohol consumption influence serum urate levels and gout risk [10-13]. Beer and spirits (but not wine) intake is positively correlated with serum urate and the relative risk of gout increases with increasing alcohol (particularly beer) consumption in men $[10,14]$. Recently, in a Japanese male sample set there was evidence for a $L R P 2$-environment interaction, where there was a significantly increased risk conferred by the rs 2544390 TT genotype for hyperuricemia with increased alcohol consumption [15].

This study aimed to test for an association of LRP2 rs 2544390 with gout and serum urate in European Caucasian and Eastern and Western Polynesian ancestral groups of New Zealand. The interaction of alcohol consumption with genotype was also evaluated.

\section{Methods}

\section{Study participants}

The New Zealand subjects consisted of gout cases clinically ascertained by the American College of Rheumatology criteria [16]. The comparison group was self-reported in their lack of a diagnosis of gouty arthritis. Recruitment was during the period 2006 to 2012. All variables except for biochemical measurements and body mass index (BMI) were self-reported. Demographic and clinical data are reported in Additional file 1: Table S1. For initial genetic analysis subjects were divided into four ancestral groups [2]; European Caucasian (555 cases, 282 controls), Eastern Polynesian (EP; Cook Island and NZ Māori; 374 cases, 533 controls), Western Polynesian (WP; Samoa, Tonga, Niue, Tuvalu and Tokelau; 285 cases, 165 controls) and mixed Eastern and Western Polynesian (EP/WP; 21 cases, 18 controls). A separate Māori sample set from the rohe (area) of the Ngati Porou iwi (tribe) from the Tairawhiti region on the East Coast of the North Island of New Zealand was included, ascertained as described above (196 cases, 207 controls). This sample set was recruited in collaboration with Ngati Porou Hauora (health service) (NPH). The New Zealand Multi-Region Ethics Committee (MEC/105/10/130) granted ethical approval, with the Northern Y Region Health Research Ethics Committee granting ethical approval for the Ngati Porou Hauora study (NTY07/07/074). All participants gave fully informed written consent for taking part in the study.

Data from the Framingham Heart Study (FHS) (Generation 3 only) and Atherosclerosis Risk in Communities (ARIC) cohorts were also used for evaluating associations with serum urate in European Caucasians. The approval number was \#834 for accessing data from the ARIC and FHS studies under the project name 'The Genetic Basis of Gout.' Subjects from the ARIC and FHS studies who self- reported as taking diuretic medication, who were first degree related and who were not of European Caucasian ancestry were excluded. The ARIC dataset consisted of 4,144 individuals and the FHS of 3,047 individuals.

\section{Data collection}

Serum urate levels were measured for NZ subjects by the uricase oxidation method, the end point determined by a Roche chemistry modular P/D analyzer. In all data sets, alcohol consumption was obtained by food frequency questionnaire. NZ participants were asked at recruitment how many servings of beer, spirits, wine and other alcohol were consumed in the previous week. For conversion of servings/week intake into g/week intake, values were multiplied by the estimated quantities of alcohol in each category of drink (beer $=10 \mathrm{~g} / 300 \mathrm{ml}$ serving; wine $=15 \mathrm{~g} / 200 \mathrm{ml}$ serving; spirits $=10 \mathrm{~g} /$ serving; other $=10 \mathrm{~g} /$ serving). For ARIC, alcohol data were supplied as g/day (from examination 1 in the years 1987 to 1989) usage and converted into g/week for this study. For FHS, alcohol intake data were obtained as number of servings per week (beer, wine and liquors) (from visit 1 for Generation 3 in the years 2002 to 2005) and converted into g/week alcohol as described above. Serum urate data were obtained from examination 1 for ARIC and visit 1 for FHS.

\section{Sample preparation and genotyping}

Separated white blood cells were used for DNA preparation by the guanidine hydrogen chloride method with chloroform extraction [17]. Taqman ${ }^{\circ}$ genotyping for rs2544390 was performed using a Lightcycler ${ }^{\circ} 480$ RealTime Polymerase Chain Reaction System (Roche Applied Science, Indianapolis, IN, USA) in 384 well plates. The FHS cohort had been genotyped by the Affymetrix SNP 5 platform and a custom designed gene-centric $50 \mathrm{~K} \mathrm{SNP}$ platform and rs2544390 genotype was imputed using MACH1 v1.0.15 with the HapMap2 CEU sample set as reference haplotypes. In the ARIC sample set rs 2544390 had been genotyped on the Affymetrix SNP 6 platform.

When comparing with the data of Hamajima et al. [15], it was important to be certain about allele assignments at rs 2544390 - uncertainties can arise when allele prevalences are approximately $50 \%$ as is the case in the Japanese population. Our Taqman-generated genotypes were $100 \%$ concordant with genotype data generated by the Affymetrix Axiom genotyping platform in a subset of $66 \mathrm{NZ}$ samples. Furthermore, the $C$ allele is the major allele in European Caucasian [18], consistent with our Taqman genotype data. We confirmed consistency in allele assignment between our and the Hamajima et al. [15] data by genotyping using Taqman 15 samples (5 CC, 5 CT, 5 TT) from the Hamajima et al. study. 


\section{Statistical analysis}

Regression analysis was used to investigate relationships between the variables in this study. For continuous response variables, this involved standard linear regression. For binary response variables (that is, discrete variables with only two levels), logistic regression was used. Both main effects and interaction terms were included in the models where appropriate. The adjusted OR for a single explanatory variable was obtained by using the logistic regression coefficient. An adjusted OR for the same variable was obtained by including additional variables in the logistic regression model, again taking the value of the model coefficient relating to the variable in question. Logistic regression analysis was used to assess the association between gout (binary response variable) and alcohol consumption and LRP2 genotype (explanatory variables), and linear regression analysis was used to assess the association between serum urate levels (response variable), and alcohol consumption and LRP2 genotype (explanatory variables). Unstandardized regression coefficients are reported. Main effects were included in the model for alcohol consumption and $L R P 2$, and for the covariates age, sex, BMI and sugar-sweetened beverage consumption. Individuals with missing data from any variable were excluded from analysis. An interaction term between alcohol consumption (both as a continuous and a binary variable) and rs2544390 genotype (binary: those who had at least one $\mathrm{T}$ allele $(\mathrm{T} / \mathrm{C}$ or $\mathrm{T} / \mathrm{T})$ and those with none $(\mathrm{C} / \mathrm{C})$ ) was also included. All analysis was done using Intercooled STATA $^{\mathrm{TM}}$ software version 8.0 (College Station, TX 77845, USA). Meta-analysis of allele counts was performed in $\mathrm{R}$ within STATA ${ }^{\mathrm{Tm}}$ using rmeta [19] to calculate combined ORs and to evaluate heterogeneity between studies. Coefficients with $P \leq 0.05$ were considered to indicate a nominally significant association between the response and explanatory variables.

\section{Results}

In the individual sample sets there was evidence for association of rs 2544390 with gout in the European Caucasian sample set (Table $1 ; \mathrm{OR}_{\text {Unadjusted }}=0.79, P=0.02$; $\left.\mathrm{OR}_{\text {Adjusted }}=0.73, P=0.07\right)$. However, there was no evidence for association when all groups were combined in meta-analysis (Figure $1 \mathrm{~A} ; \mathrm{OR}=1.06, P=0.36$ ) although the $P_{\text {Het }}=0.015$ in the meta-analysis suggested some heterogeneity. A potential source of heterogeneity was ancestry; therefore, groups were combined by metaanalysis in ancestral-specific groups. This analysis revealed the $\mathrm{T}$ allele to be associated with increased gout risk in people of Māori and Pacific ancestry (Figure 1B; $\mathrm{OR}=1.20, P=0.009)$ with, in contrast to the effect in European Caucasian, the minor allele conferring risk (Table 1; Figure 1A). There was no evidence for an association of rs 2544390 with serum urate by linear regression testing in non-gout (including ARIC and FHS) sample sets (Table 2).

Alcohol intake was positively associated with serum urate in unstratified European Caucasian and Māori and Pacific Island control sample sets (Table 3 and Additional file 1: Table S2; adjusted $\beta=0.00007 \mathrm{mmol} / \mathrm{L}, P=1.98 \times 10^{-9}$ and $\beta=0.00008, P=0.014$ respectively). No significant association of serum urate with alcohol consumption was observed in gout sample sets of both ancestries (Table 3). However, we note that this analysis would be compromised by urate-lowering therapy. We did not adjust for this, given the lack of data on adherence to medication.

Alcohol intake, when analyzed as a continuous variable (g/week), was positively associated with risk of gout in the Māori and Pacific but not NZ European Caucasian sample sets (Table 4 and Additional file 1: Table S3; adjusted OR = 1.002, $P=0.004$ and $\mathrm{OR}=1.001, P=0.26$, respectively). Any alcohol intake, when analyzed as a dichotomized variable, was associated with a $36 \%$ increase in risk of gout

Table 1 Association analysis of rs2544390 with gout

\begin{tabular}{|c|c|c|c|c|c|c|c|c|c|c|c|c|}
\hline \multirow[t]{2}{*}{ Sample set } & \multicolumn{4}{|c|}{$\begin{array}{c}\text { Case genotypes, } \\
\text { number (frequency) }\end{array}$} & \multicolumn{4}{|c|}{$\begin{array}{l}\text { Control genotypes, } \\
\text { number (frequency) }\end{array}$} & \multicolumn{2}{|c|}{ Unadjusted } & \multicolumn{2}{|c|}{ Adjusted } \\
\hline & $\mathrm{CC}$ & CT & TT & $\begin{array}{c}\mathrm{T} \\
\text { frequency }\end{array}$ & CC & CT & TT & $\begin{array}{c}\mathrm{T} \\
\text { frequency }\end{array}$ & $\begin{array}{c}\text { Allelic OR, } \\
(95 \% \mathrm{Cl})\end{array}$ & $P$ & $\begin{array}{c}\text { Allelic OR, } \\
\text { (95\% CI) }\end{array}$ & $P$ \\
\hline European Caucasian & $\begin{array}{c}206 \\
(0.371)\end{array}$ & $\begin{array}{c}272 \\
(0.490)\end{array}$ & $\begin{array}{c}77 \\
(0.139)\end{array}$ & $\begin{array}{c}426 \\
(0.384)\end{array}$ & $\begin{array}{c}95 \\
(0.337)\end{array}$ & $\begin{array}{c}125 \\
(0.443)\end{array}$ & $\begin{array}{c}62 \\
(0.220)\end{array}$ & $\begin{array}{c}249 \\
(0.441)\end{array}$ & $\begin{array}{c}0.79 \\
(0.64-0.97)\end{array}$ & 0.02 & $\begin{array}{c}0.73 \\
(0.52-1.03)\end{array}$ & 0.07 \\
\hline Eastern Polynesian & $\begin{array}{c}63 \\
(0.168)\end{array}$ & $\begin{array}{c}166 \\
(0.444)\end{array}$ & $\begin{array}{c}145 \\
(0.388)\end{array}$ & $\begin{array}{c}456 \\
(0.610)\end{array}$ & $\begin{array}{c}94 \\
(0.176)\end{array}$ & $\begin{array}{c}257 \\
(0.482)\end{array}$ & $\begin{array}{c}182 \\
(0.341)\end{array}$ & $\begin{array}{c}621 \\
(0.583)\end{array}$ & $\begin{array}{c}1.11 \\
(0.92-1.35)\end{array}$ & 0.26 & $\begin{array}{c}1.09 \\
(0.82-1.44)\end{array}$ & 0.54 \\
\hline $\begin{array}{c}\text { Mixed Eastern Western } \\
\text { Polynesian }\end{array}$ & $\begin{array}{c}4 \\
(0.191)\end{array}$ & $\begin{array}{c}7 \\
(0.333)\end{array}$ & $\begin{array}{c}10 \\
(0.476)\end{array}$ & $\begin{array}{c}27 \\
(0.643)\end{array}$ & $\begin{array}{c}3 \\
(0.167)\end{array}$ & $\begin{array}{c}9 \\
(0.500)\end{array}$ & $\begin{array}{c}6 \\
(0.333)\end{array}$ & $21(0.583)$ & $\begin{array}{c}1.25 \\
(0.53-2.96)\end{array}$ & 0.61 & $\begin{array}{c}9.15 \\
(0.96-87.65)\end{array}$ & 0.05 \\
\hline Western Polynesian & $\begin{array}{c}18 \\
(0.063)\end{array}$ & $\begin{array}{c}129 \\
(0.453)\end{array}$ & $\begin{array}{c}138 \\
(0.484)\end{array}$ & $\begin{array}{c}405 \\
(0.711)\end{array}$ & $\begin{array}{c}24 \\
(0.145)\end{array}$ & $\begin{array}{c}66 \\
(0.400)\end{array}$ & $\begin{array}{c}75 \\
(0.455)\end{array}$ & $\begin{array}{c}216 \\
(0.655)\end{array}$ & $\begin{array}{c}1.30 \\
(0.97-1.75)\end{array}$ & 0.08 & $\begin{array}{c}1.21 \\
(0.82-1.77)\end{array}$ & 0.33 \\
\hline Ngati Porou Hauora & $\begin{array}{c}25 \\
(0.120)\end{array}$ & $\begin{array}{c}93 \\
(0.447)\end{array}$ & $\begin{array}{c}78 \\
(0.375)\end{array}$ & $\begin{array}{c}249 \\
(0.635)\end{array}$ & $\begin{array}{c}38 \\
(0.179)\end{array}$ & $\begin{array}{c}101 \\
(0.476)\end{array}$ & $\begin{array}{c}68 \\
(0.321)\end{array}$ & $\begin{array}{c}237 \\
(0.572)\end{array}$ & $\begin{array}{c}1.30 \\
(0.98-1.73)\end{array}$ & 0.07 & $\begin{array}{c}1.25 \\
(0.83-1.88)\end{array}$ & 0.29 \\
\hline
\end{tabular}

Adjusted against sex, age, body mass index, sugar-sweetened beverage (SSB) consumption (number of drinks/day) and alcohol consumption (g/week). $\mathrm{Cl}$, confidence interval; OR, odds ratio. 


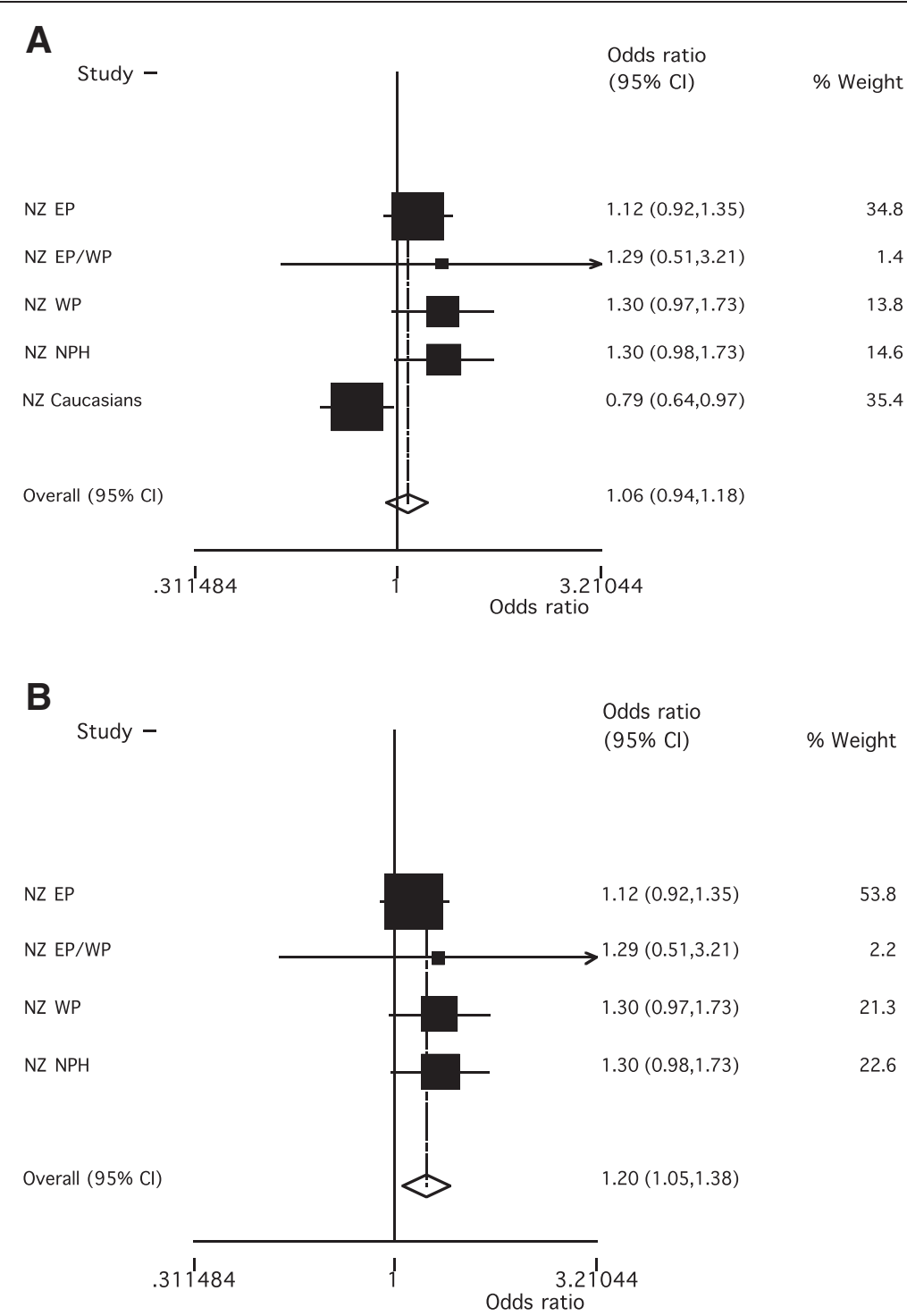

Figure 1 Meta-analysis of association of $r s 2544390$ with gout. A) with gout in all study groups $\left(P_{\text {Het }}=0.015\right.$ and $\left.P_{\mathrm{OR}}=0.36\right)$, B) with gout in NZ Māori and Pacific Island groups $\left(P_{\text {Het }}=0.774\right.$ and $\left.P_{\mathrm{OR}}=0.009\right)$.

in Māori and Pacific Island $(\mathrm{OR}=1.36 ; P=0.03)$, with no increase in gout risk observed in the NZ European Caucasian sample set $(\mathrm{OR}=0.96 ; P=0.86)$ (Table 4 and Additional file 1: Table S3). Examining alcohol types revealed evidence for an association of beer consumption with risk of gout in European Caucasian and Māori and Pacific Island groups and spirit consumption with risk of gout in European Caucasian (Table 4). There was evidence for consumption of wine associating with a reduced risk of gout in European Caucasian (Table 4).

We then tested for interaction between alcohol consumption and rs2544390 genotype (Table 5). Evidence for nonadditive interaction was observed in the combined Māori and Pacific Island sample set when alcohol consumption was analyzed either as a continuous $\left(P_{\text {Adjusted }}=0.001\right)$ or dichotomized variable $\left(P_{\text {Adjusted }}=0.001\right)$ but not in European

Table 2 Association of $r s 2544390$ and serum urate (mmol/L)

\begin{tabular}{cccccc}
\hline Ancestral group & Number & Unadjusted $\beta$-coeff $(\mathbf{9 5 \%} \mathrm{Cl})$ & $\boldsymbol{P}$-value & Adjusted $\boldsymbol{\beta}$-coeff $(\mathbf{9 5} \% \mathrm{Cl})$ & $\boldsymbol{P}$-value \\
\hline All European Caucasian non-gout & 7451 & $-0.00099(-0.0029$ to 0.0049$)$ & 0.62 & $-0.00029(-0.0041$ to 0.0035$)$ & 0.88 \\
NZ Māori and Pacific Island non-gout & 775 & $0.0068(-0.0095$ to 0.0232$)$ & 0.41 & $-0.0015(-0.016$ to 0.013$)$ & 0.84 \\
\hline
\end{tabular}

Adjusted against sex, age, body mass index, sugar-sweetened beverage consumption (number of drinks/day) and study data set. The sample sets of Māori and Pacific Island ancestry are adjusted for the number of self-reported Māori and/or Pacific Island grandparents. Cl, confidence interval; NZ, New Zealand. 
Table 3 Association of alcohol intake (g/week) with serum urate (mmol/L)

\begin{tabular}{ccc}
\hline Study group & $\boldsymbol{\beta ( 9 5 \% ~ C l )}$ & $\boldsymbol{P}$-value \\
\hline $\begin{array}{c}\text { All European Caucasian } \\
\text { non-gout }\end{array}$ & $0.00007(0.00004$ to 0.00009$)$ & $1.98 \mathrm{E}-09$ \\
$\begin{array}{c}\text { NZ Māori and Pacific Island } \\
\text { non-gout }\end{array}$ & $0.00008(0.00001$ to 0.00014$)$ & 0.014 \\
$\begin{array}{c}\text { NZ European Caucasian } \\
\text { gout }\end{array}$ & $0.000007(-0.00012$ to 0.00013$)$ & 0.91 \\
$\begin{array}{c}\text { NZ Māori and Pacific Island } \\
\text { gout }\end{array}$ & $0.00007(-0.00001$ to 0.00015$)$ & 0.10 \\
\hline
\end{tabular}

Adjusted against sex, age, body mass index, sugar-sweetened beverage consumption (number of drinks/day) and study data set. The sample sets of Māori and Pacific Island ancestry are adjusted for the number of self-reported Māori and/or Pacific Island grandparents. $\mathrm{Cl}$, confidence interval; NZ, New Zealand.

Table 4 Association of alcohol intake with gout

\begin{tabular}{|c|c|c|c|c|c|}
\hline \multirow[b]{2}{*}{ Alcohol group } & \multicolumn{4}{|c|}{$\begin{array}{c}\text { Alcohol consumption as continuous } \\
\text { variable (g/week) }\end{array}$} & \multirow[b]{2}{*}{$P$} \\
\hline & Obs. & $\begin{array}{l}\text { Unadjusted } \\
\text { OR }(95 \% \mathrm{Cl})\end{array}$ & $P$ & $\begin{array}{c}\text { Adjusted OR } \\
(95 \% \mathrm{Cl})\end{array}$ & \\
\hline \multicolumn{6}{|l|}{ All alcohol types } \\
\hline $\begin{array}{l}\text { NZ European } \\
\text { Caucasian }\end{array}$ & 837 & $\begin{array}{c}1.000 \\
\text { (0.999 to } 1.002)\end{array}$ & 0.74 & $\begin{array}{c}1.001 \\
\text { (0.999 to } 1.004)\end{array}$ & 0.26 \\
\hline $\begin{array}{l}\text { NZ Māori and } \\
\text { Pacific Island }\end{array}$ & 1,799 & $\begin{array}{c}1.001 \\
\text { (0.999 to } 1.002)\end{array}$ & 0.07 & $\begin{array}{c}1.002 \\
(1.001 \text { to } 1.003)\end{array}$ & 0.004 \\
\hline \multicolumn{6}{|l|}{ Beer } \\
\hline $\begin{array}{l}\text { NZ European } \\
\text { Caucasian }\end{array}$ & 837 & $\begin{array}{c}1.002 \\
(0.999 \text { to } 1.004)\end{array}$ & 0.11 & $\begin{array}{c}1.003 \\
(1.000 \text { to } 1.006)\end{array}$ & 0.03 \\
\hline $\begin{array}{l}\text { NZ Māori and } \\
\text { Pacific Island }\end{array}$ & 1,799 & $\begin{array}{c}1.002 \\
(1.001 \text { to } 1.003)\end{array}$ & 0.002 & $\begin{array}{c}1.003 \\
\text { (1.001 to } 1.004)\end{array}$ & 0.002 \\
\hline \multicolumn{6}{|l|}{ Wine } \\
\hline $\begin{array}{l}\text { NZ European } \\
\text { Caucasian }\end{array}$ & 837 & $\begin{array}{c}0.998 \\
(0.996 \text { to } 1.000)\end{array}$ & 0.10 & $\begin{array}{c}0.999 \\
\text { (0.996 to } 1.001)\end{array}$ & 0.33 \\
\hline $\begin{array}{l}\text { NZ Māori and } \\
\text { Pacific Island }\end{array}$ & 1,799 & $\begin{array}{c}0.998 \\
\text { (0.994 to } 1.002)\end{array}$ & 0.28 & $\begin{array}{c}1.000 \\
(0.996 \text { to } 1.005)\end{array}$ & 0.84 \\
\hline \multicolumn{6}{|l|}{ Spirits } \\
\hline $\begin{array}{l}\text { NZ European } \\
\text { Caucasian }\end{array}$ & 837 & $\begin{array}{c}1.002 \\
\text { (0.999 to } 1.006)\end{array}$ & 0.21 & $\begin{array}{c}1.005 \\
(1.000 \text { to } 1.011)\end{array}$ & 0.05 \\
\hline $\begin{array}{l}\text { NZ Māori and } \\
\text { Pacific Island }\end{array}$ & 1,799 & $\begin{array}{c}0.999 \\
(0.997 \text { to } 1.001)\end{array}$ & 0.40 & $\begin{array}{c}1.001 \\
(0.998 \text { to } 1.005)\end{array}$ & 0.54 \\
\hline
\end{tabular}

\begin{tabular}{|c|c|c|c|c|c|}
\hline \multirow[b]{2}{*}{ All alcohol types } & \multicolumn{5}{|c|}{$\begin{array}{l}\text { Alcohol consumption as dichotomized variable } \\
\text { (No alcohol versus any alcohol intake) }\end{array}$} \\
\hline & & & & & \\
\hline $\begin{array}{l}\text { NZ European } \\
\text { Caucasian }\end{array}$ & 837 & $\begin{array}{c}0.79 \\
\text { (0.54 to } 1.15)\end{array}$ & 0.22 & $\begin{array}{c}0.96 \\
(0.56 \text { to } 1.62)\end{array}$ & 0.86 \\
\hline $\begin{array}{l}\text { NZ Māori and } \\
\text { Pacific Island }\end{array}$ & 1,799 & $\begin{array}{c}0.98 \\
(0.80 \text { to } 1.19)\end{array}$ & 0.83 & $\begin{array}{c}1.36 \\
(1.03 \text { to } 1.79)\end{array}$ & 0.03 \\
\hline \multicolumn{6}{|l|}{ Beer } \\
\hline $\begin{array}{l}\text { NZ European } \\
\text { Caucasian }\end{array}$ & 837 & $\begin{array}{c}1.26 \\
(0.93 \text { to } 1.69)\end{array}$ & 0.13 & $\begin{array}{c}1.32 \\
\text { (0.88 to } 1.98)\end{array}$ & 0.17 \\
\hline $\begin{array}{l}\text { NZ Māori and } \\
\text { Pacific Island }\end{array}$ & 1,799 & $\begin{array}{c}1.55 \\
(1.26 \text { to } 1.90)\end{array}$ & $\begin{array}{l}2.4 \times \\
10^{-5}\end{array}$ & $\begin{array}{c}1.37 \\
(1.03 \text { to } 1.81)\end{array}$ & 0.03 \\
\hline
\end{tabular}

Table 4 Association of alcohol intake with gout (Continued)

\begin{tabular}{|c|c|c|c|c|c|}
\hline \multicolumn{6}{|l|}{ Wine } \\
\hline $\begin{array}{l}\text { NZ European } \\
\text { Caucasian }\end{array}$ & 837 & $\begin{array}{c}0.60 \\
\text { (0.45 to } 0.81 \text { ) }\end{array}$ & 0.001 & $\begin{array}{c}0.66 \\
(0.46 \text { to } 0.95)\end{array}$ & 0.03 \\
\hline $\begin{array}{l}\text { NZ Māori and } \\
\text { Pacific Island }\end{array}$ & 1,799 & $\begin{array}{c}0.66 \\
\text { (0.48 to } 0.90)\end{array}$ & 0.009 & $\begin{array}{c}1.44 \\
\text { (0.93 to } 2.23)\end{array}$ & 0.11 \\
\hline \multicolumn{6}{|l|}{ Spirits } \\
\hline $\begin{array}{l}\text { NZ European } \\
\text { Caucasian }\end{array}$ & 837 & $\begin{array}{c}1.22 \\
\text { (0.86 to } 1.75)\end{array}$ & 0.27 & $\begin{array}{c}1.59 \\
\text { (1.02 to } 2.48)\end{array}$ & 0.04 \\
\hline $\begin{array}{l}\text { NZ Māori and } \\
\text { Pacific Island }\end{array}$ & 1,799 & $\begin{array}{c}0.70 \\
\text { (0.52 to } 0.94)\end{array}$ & 0.017 & $\begin{array}{c}1.30 \\
\text { (0.86 to } 1.94)\end{array}$ & 0.21 \\
\hline
\end{tabular}

Adjusted against sex, age, body mass index, sugar-sweetened beverage consumption (number of drinks/day) and study data set. The sample sets of Mãori and Pacific Island ancestry are adjusted for the number of self-reported Māori and/or Pacific Island grandparents. $\mathrm{Cl}$, confidence interval, $\mathrm{NZ}$, New Zealand, Obs = Number of observations; OR, odds ratio.

Caucasian. To visualize the nature of the interaction between alcohol consumption and rs2544390, adjusted ORs were calculated in four groups with T-allele negative and no alcohol consumption being the referent group (Table 6 and Additional file 1: Table S4). Within the Māori and Pacific Island T-allele negative group there was a 4.18-fold increase in risk with any exposure to alcohol $\left(P=6.6 \times 10^{-5}\right)$ compared to a 1.14-fold increase within the T-allele positive group $(P=0.40)$. Within the different alcohol categories for the Māori and Pacific Island group there was a significant interaction term for risk of gout for beer consumption (dichotomized variable; OR $=0.43(0.21$ to 0.90$\left.), P_{\text {Adjusted }}=0.026\right)$ but not for wine (dichotomized variable; $\mathrm{OR}=0.68$ (0.23 to $\left.1.95), P_{\text {Adjusted }}=0.47\right)$ or spirit (dichotomized variable; $\mathrm{OR}=0.50(0.18$ to 1.34$\left.), P_{\text {Adjusted }}=0.18\right)$ consumption.

\section{Discussion}

Our study reports association of the $\mathrm{T}$ allele of $L R P 2$ rs2544390 with gout risk in NZ Mãori and Pacific Island

Table 5 Interaction terms between alcohol intake and rs2544390 genotype for gout risk

\begin{tabular}{cccc}
\hline \multicolumn{4}{c}{ Alcohol consumption as continuous variable } \\
\hline & Obs. & OR (95\% Cl) & $P$ \\
\hline NZ European Caucasian & 837 & $0.996(0.991$ to 1.002) & 0.18 \\
NZ Māori and Pacific Island & 1,799 & $0.992(0.987$ to 0.997) & 0.001 \\
\hline \multicolumn{4}{c}{ Alcohol consumption as dichotomized variable (No alcohol } \\
(reference) versus any alcohol intake) & 0.15 \\
\hline NZ European Caucasian & 837 & $0.45(0.15$ to 1.34) & 0.001 \\
NZ Māori and Pacific Island & 1,799 & $0.27(0.13$ to 0.57) &
\end{tabular}

Adjusted against sex, age, body mass index, sugar-sweetened beverage consumption (number of drinks/day) and study data set. The sample sets of Māori and Pacific Island ancestry are adjusted for the number of self-reported Māori and/or Pacific Island grandparents. Cl, confidence interval; NZ, New Zealand; Obs = Number of observations; OR, odds ratio. 


\begin{tabular}{|c|c|c|c|c|}
\hline \multirow[t]{2}{*}{ Study group } & \multicolumn{2}{|c|}{ No alcohol } & \multicolumn{2}{|c|}{ Any alcohol intake } \\
\hline & OR $(95 \% \mathrm{Cl})$ & $P$ & OR $(95 \% \mathrm{Cl})$ & $P$ \\
\hline \multicolumn{5}{|c|}{ NZ European Caucasian } \\
\hline T- & 1.00 & 1 & $\begin{array}{c}1.57 \\
\text { (0.68 to } 3.63)\end{array}$ & 0.29 \\
\hline T+ & $\begin{array}{c}1.45 \\
\text { (0.58 to } 3.61)\end{array}$ & 0.43 & $\begin{array}{c}1.02 \\
(0.48 \text { to } 2.19)\end{array}$ & 0.95 \\
\hline \multicolumn{5}{|c|}{$\begin{array}{l}\text { NZ Māori } \\
\text { and Pacific Island }\end{array}$} \\
\hline T- & 1.00 & 1 & $\begin{array}{c}4.18 \\
\text { (2.07 to } 8.44)\end{array}$ & $6.61 \times 10^{-5}$ \\
\hline $\mathrm{T}+$ & $\begin{array}{c}2.68 \\
\text { (1.54 to } 4.66)\end{array}$ & $4.83 \times 10^{-4}$ & $\begin{array}{c}3.01 \\
(1.72 \text { to } 5.28)\end{array}$ & $1.13 \times 10^{-4}$ \\
\hline
\end{tabular}

Adjusted against age, sex, body mass index, sugar-sweetened beverage consumption (number of drinks/day) and study data set. The sample sets of Māori and Pacific Island ancestry are adjusted for the number of self-reported Mãori and/or Pacific Island grandparents. $\mathrm{Cl}$, confidence interval; NZ, New Zealand; OR, odds ratio.

samples $(\mathrm{OR}=1.20, P=0.009$; Figure $1 \mathrm{~A})$. This observation is consistent with the reported association with increased serum urate and gout risk $(\mathrm{OR}=1.32)$ of this allele in Japanese sample sets [5,6], supporting the conclusion that LRP2 rs2544390 is a genuine risk factor for increased serum urate and gout in South East Asia and Oceania. In contrast, there was marginal evidence for association of $r s 2544390$ with gout risk in European Caucasian, but in an opposing direction $\left(\mathrm{OR}=0.79, P_{\text {Unadjusted }}=0.02\right)$. Heterogeneity (allelic and genetic) is also evident in gene associations with gout between among South East Asian, Polynesian and European Caucasian at SLC2A9 and $A B C G 2$ (reviewed in [20]). If the association in European Caucasian were to be confirmed this would allow the inference that $r s 2544390$ is not causal. It could also be inferred that haplotypic structure would substantially differ at this locus in the two ancestral groupings, aiding in fine-mapping the causal variant. With respect to the location of the putative causal variant, in European Caucasian rs2544390 is located (using 1,000 Genomes data) in a 40-kilobase haplotype block (SNPs with intermarker LD $\mathrm{r}^{2}>0.8$ ) from 170.165 to $170.205 \mathrm{Mb}$ on chromosome 2 wholly within LRP2; however, in Japanese the block is smaller at only 4-kilobases (170.201 to $170.205 \mathrm{Mb}$ ), spanning exons 84 and 85 . This information would substantially reduce the amount of genome needing to be searched in fine-mapping the etiological variant.

There was a positive association between alcohol intake and serum urate in Māori and Pacific Island and European Caucasian control sample sets (Table 3 ) and between alcohol intake and risk of gout in Māori and Pacific Island only (Table 4). With respect to Māori and Pacific Island our data can be compared with that of Evans et al. [21] who observed that serum urate increases with reported alcohol intake in men of all ages of Polynesian ancestry.
They also observed a higher prevalence of gout in people with high alcohol consumption. We confirm the relationship between alcohol intake, serum urate and risk of gout in people of Māori and Pacific Island ancestry, in a larger sample set and using contemporary statistical techniques that are able to adjust for potential measured confounders. As has previously been documented in European Caucasian [10], beer was more strongly associated with risk of gout than spirits in the Māori and Pacific Island samples, with no evidence for an association of wine consumption with risk of gout. In the NZ European Caucasian samples, the evidence for an association with risk of gout was strongest with beer and spirits consumption. However, in contrast to the Choi et al. study [10], we observed a protective relationship between wine consumption and risk of gout. Why this is the case is unclear, with confounding by other dietary behaviors a possible explanation. With respect to total alcohol consumption and gout risk in European Caucasian, the small NZ control sample size $(\mathrm{n}=282)$ likely did not provide the power to detect a significant relationship. When alcohol intake was analyzed as a continuous variable, the direction and magnitude of the effect was similar in NZ European Caucasian to that in the Māori and Pacific Island sample set (Table 4).

There was evidence of non-additive interaction between rs2544390 genotype and alcohol consumption (Table 5; $\left.P_{\text {Interaction }}=0.001\right)$ in the combined Mãori and Pacific Island sample set in determining the risk of gout. The interaction was manifest by the normally protective genotype (CC) at rs 2544390 conferring a significantly elevated risk of gout in alcohol drinkers compared to non-drinkers (Table 6). If this interaction is proven robust by replication, understanding of the biological mechanism may generate new knowledge on the role of alcohol in the etiology of gout, with the current paradigm dictating that alcohol increases urate by generation of purines in the bloodstream (mostly by hepatic metabolism). Alcohol exposure appears to over-ride the protective effect of the CC genotype. However, this observation is not consistent with Hamajima et al. [15]. In this study, they observed association of the TT genotype with the highest risk of hyperuricemia in male subjects consuming $\geq 5$ alcoholic drinks per week $(\mathrm{OR}=3.30)$. We undertook a similar analysis in men in the combined Māori and Pacific Island non-gout sample set (Additional file 1: Table S5). In our analysis the CC genotype was associated with the highest risk of hyperuricemia in those drinking $\geq 100 \mathrm{~g}$ of alcohol per week (OR = 4.48). Also, using the Hamajima et al. [15] data, we produced a similar analysis in men to that in Table 6 (Additional file 1: Table S5). The CC genotype group in the NZ Māori and Pacific Island sample had the highest risk for gout with alcohol exposure $(\mathrm{OR}=3.96)$ whereas 
the CC genotype group exhibited neutral risk for hyperuricemia in the Japanese sample set $(\mathrm{OR}=0.99)$. Thus, while the Hamajima et al. and our results both report non-additive interaction between alcohol consumption and rs 2544390 in hyperuricemia and gout, respectively, homozygosity for different alleles is associated with the highest risk upon exposure to alcohol. Given the consistency in rs2544390 association with serum urate and gout risk between Māori and Pacific Island, and Japanese [5] (risk allele T), there is no obvious explanation for this discrepancy. Noting that there was no main effect association of $r s 2544390$ with serum urate in either European or Māori and Pacific Island control sample sets (Table 2), it is possible that the $r s 2544390$ association with gout and the alcohol-genotype interaction influencing gout risk in Polynesians is by a mechanism separate to the control of serum urate. It will be very important to observe non-additive interaction(s) between alcohol consumption and rs 2544390 in control of serum urate and gout in other datasets of South East Asian and Oceanic origin.

\section{Conclusions}

The LRP2 rs2544390 SNP is associated with gout in people of Māori and Pacific ancestry, in a direction consistent with the previously reported effect on serum urate in Japanese. There is evidence for an opposing effect in European Caucasians, although this remains to be replicated. The genetic discrimination in risk of gout mediated by $r s 2544390$ is ablated by alcohol consumption in the NZ Māori and Pacific population. Further exploration of the mechanism underlying this interaction should generate new knowledge on the role of alcohol in gout, in addition to strengthening the evidence base for reduction of alcohol consumption in the management of gout.

\section{Additional file}

Additional file 1: Table S1. Demographic and clinical characteristics of study participants. Table S2: Association analysis of alcohol intake ( $\mathrm{g} /$ week) with serum urate $(\mathrm{mmol} / \mathrm{L})$. Table S3: Association analysis of alcohol intake (g/week) with risk of gout. Table S4: Alcohol intake and gout risk for genotypically stratified groups in individual sample sets. Table S5: Top: Risk for hyperuricemia (serum urate $\geq 0.41 \mathrm{mmol} / \mathrm{L}$ ) among Japanese (gout and non-gout) and NZ Māori and Pacific Island (non-gout) males according to alcohol consumption and rs2544390 genotype categories. Bottom: Risk for hyperuricemia amongst Japanese (gout and non-gout) males and for gout amongst NZ Māori and Pacific Island males according to alcohol consumption and rs2544390 genotype categories.

\section{Abbreviations}

ARIC: Atherosclerosis risk in communities; BMI: Body mass index; CEU: Centre d'Etude du Polymorphisme Humain from Utah; Cl: Confidence interval; EP: Eastern Polynesian; FHS: Framingham heart study; LRP2: Lipoprotein receptor-related protein 2; NPH: Ngati Porou Hauora; OR: Odds ratio; SNP: Single nucleotide polymorphism; WP: Western Polynesian.

\section{Competing interests}

The authors declare that they have no competing interests.

\section{Authors' contributions}

HR and TRM helped to design the study, oversee its execution, and prepare the manuscript. JEH-M, JHH, CF, ND, PBJ, DHNW and LKS helped to provide clinical recruitment and prepare the manuscript. AP-G and RT helped to collect data and prepare the manuscript. All authors read and approved the final manuscript.

\section{Acknowledgements}

This work was supported by the Health Research Council of New Zealand, Arthritis New Zealand, New Zealand Lottery Health and the University of Otago. The authors would like to thank Ria Akuhata and Nancy Aupouri (Ngati Porou Hauora), and Jill Drake, Roddi Laurence and Gabrielle Sexton for recruitment, and Murray Cadzow and Marilyn Merriman for technical assistance. We thank Labtests (Auckland) for their assistance in recruitment. We also thank Nobuyuki Hamajima for collaborating in confirming genotypes at rs2544390. The Atherosclerosis Risk in Communities and Framingham Heart study analyses (project \#834) were approved by the relevant Database of Genotype and Phenotype (dbGaP; [22]) Data Access Committees. The Atherosclerosis Risk in Communities Study is carried out as a collaborative study supported by National Heart, Lung, and Blood Institute contracts

N01-HC-55015, N01-HC-55016, N01-HC-55018, N01-HC-55019, N01-HC-55020, N01-HC-55021, N01-HC-55022, R01HL087641, R01HL59367 and R01HL086694; National Human Genome Research Institute contract U01HG004402; and National Institutes of Health contract HHSN268200625226C. The authors thank the staff and participants of the ARIC study for their important contributions. Infrastructure was partly supported by Grant Number UL1RR025005, a component of the National Institutes of Health and NIH Roadmap for Medical Research. The Framingham Heart Study and the Framingham SHARe project are conducted and supported by the National Heart, Lung, and Blood Institute (NHLBI) in collaboration with Boston University. The Framingham SHARe data used for the analyses described in this manuscript were obtained through $\mathrm{dbGaP}$. This manuscript was not prepared in collaboration with investigators of the Framingham Heart Study and does not necessarily reflect the opinions or views of the Framingham Heart Study, Boston University, or the NHLBI.

\section{Author details}

${ }^{1}$ Department of Biochemistry, University of Otago, Dunedin, New Zealand. ${ }^{2}$ Ngati Porou Hauora Charitable Trust, Te Puia Springs, New Zealand. ${ }^{3}$ Department of Medicine, University of Auckland, Auckland, New Zealand. ${ }^{4}$ Department of Rheumatology, Waikato Hospital, Hamilton, New Zealand. ${ }^{5}$ Department of Medicine, University of Otago, Christchurch, New Zealand.

Received: 2 August 2013 Accepted: 18 October 2013

Published: 4 November 2013

\section{References}

1. Köttgen A, Albrecht E, Teumer A, Vitart V, Krumsiek J, Hundertmark C, Pistis G, Ruggiero D, O'Seaghdha CM, Haller T, Yang Q, Tanaka T, Johnson AD, Kutalik Z, Smith AV, Shi J, Struchalin M, Middelberg RP, Brown MJ, Gaffo AL, Pirastu N, Li G, Hayward C, Zemunik T, Huffman J, Yengo L, Zhao JH, Demirkan A, Feitosa MF, Liu X, et al: Genome-wide association analyses identify 18 new loci associated with serum urate concentrations. Nat Genet 2013, 45:145-154.

2. Hollis-Moffatt JE, Phipps-Green AJ, Chapman B, Jones GT, van Rij A, Gow PJ, Harrison AA, Highton J, Jones PB, Montgomery GW, Stamp LK, Dalbeth N, Merriman TR: The renal urate transporter SLC17A1 locus: confirmation of association with gout.Arthritis Res Ther 2012, 14:R92.

3. Hollis-Moffatt JE, Xu X, Dalbeth N, Merriman ME, Topless R, Waddell C, Gow PJ, Harrison AA, Highton J, Jones PB, Stamp LK, Merriman TR: Role of the urate transporter SLC2A9 gene in susceptibility to gout in New Zealand Maori, Pacific Island, and Caucasian case-control sample sets. Arthritis Rheum 2009, 60:3485-3492.

4. Phipps-Green AJ, Hollis-Moffatt JE, Dalbeth N, Merriman ME, Topless R, Gow PJ, Harrison AA, Highton J, Jones PB, Stamp LK, Merriman TR: A strong role for the ABCG2 gene in susceptibility to gout in New Zealand Pacific Island and Caucasian, but not Maori, case and control sample sets. Hum Mol Genet 2010, 19:4813-4819. 
5. Kamatani Y, Matsuda K, Okada Y, Kubo M, Hosono N, Daigo Y, Nakamura Y, Kamatani N: Genome-wide association study of hematological and biochemical traits in a Japanese population.Nat Genet 2010, 42:210-215.

6. Urano W, Taniguchi A, Inoue E, Sekita C, Ichikawa N, Koseki Y, Kamatani N, Yamanaka H: Effect of genetic polymorphisms on development of gout. J Rheumatol 2013, 40:1374-1378.

7. Cabezas FL, Céspedes C, Vio CP, Bronfman M, Marzolo MP: Megalin/LRP2 expression is induced by peroxisome proliferator-activated receptor -alpha and -gamma: implications for PPARs' roles in renal function. PLoS One 2011, 6:e16794.

8. Christensen El, Birn H: Megalin and cubilin: multifunctional endocytic receptors.Nat Rev Mol Cell Biol 2002, 3:256-266.

9. Hosaka K, Takeda T, lino N, Hosojima M, Sato H, Kaseda R, Yamamoto K, Kobayashi A, Gejyo F, Saito A: Megalin and nonmuscle myosin heavy chain IIA interact with the adaptor protein Disabled-2 in proximal tubule cells. Kidney Int 2009, 75:1308-1315.

10. Choi HK, Atkinson K, Karlson EW, Willett W, Curhan G: Alcohol intake and risk of incident gout in men: a prospective study.Lancet 2004, 363:1277-1281.

11. Choi HK, Curhan G: Soft drinks, fructose consumption, and the risk of gout in men: prospective cohort study.BMJ 2008, 336:309-312.

12. Choi JW, Ford ES, Gao X, Choi HK: Sugar-sweetened soft drinks, diet soft drinks, and serum uric acid level: the Third National Health and Nutrition Examination Survey.Arthritis Rheum 2008, 59:109-116.

13. Batt C, Phipps-Green AJ, Black MA, Cadzow M, Merriman ME, Topless R, Gow P, Harrison A, Highton J, Jones P, Stamp L, Dalbeth N, Merriman TR: Sugarsweetened beverage consumption: a risk factor for prevalent gout with SLC2A9 genotype-specific effects on serum urate and risk of gout. Ann Rheum Dis 2013. doi: 10.1136/annrheumdis-2013-203600.

14. Choi HK, Curhan G: Beer, liquor, and wine consumption and serum uric acid level: the Third National Health and Nutrition Examination Survey. Arthritis Rheum 2004, 51:1023-1029.

15. Hamajima N, Naito M, Okada R, Kawai S, Yin G, Morita E, Higashibata T, Tamura T, Nakagawa H, Matsuo H, Mori A, Wakai K: Significant interaction between LRP2 rs2544390 in intron 1 and alcohol drinking for serum uric acid levels among a Japanese population.Gene 2012, 503:131-136.

16. Wallace SL, Robinson H, Masi AT, Decker JL, McCarty DJ, Yu TF: Preliminary criteria for the classification of the acute arthritis of primary gout. Arthritis Rheum 1977, 20:895-900.

17. McKinney CF, Merriman ME, Phipps-Green A, Alizadeh BZ, Koeleman BP, Dalbeth N, Gow PJ, Harrison AA, Highton J, Jones PB, Stamp LK, Steer S, Barrera P, Coenen MJ, Franke B, van Riel PL, Vyse TJ, Aitman TJ, Radstake TR, Merriman TR: Association of variation in Fcgamma receptor $3 B$ gene copy number with rheumatoid arthritis in Caucasian samples. Ann Rheum Dis 2010, 69:1711-1716

18. www.1000genomes.org.

19. Rproject.org.http://cran.rproject.org/web/packages/rmeta/index.html.

20. Merriman TR: Population heterogeneity in the genetic control of serum urate.Semin Nephrol 2011, 31:420-425.

21. Evans JG, Prior IA, Harvey HP: Relation of serum uric acid to body bulk, haemoglobin, and alcohol intake in two South Pacific Polynesian populations.Ann Rheum Dis 1968, 27:319-325.

22. www.ncbi.nlm.nih.gov/dbgap.

\section{doi:10.1186/ar4366}

Cite this article as: Rasheed et al: Association of the lipoprotein receptor-related protein 2 gene with gout and non-additive interaction with alcohol consumption. Arthritis Research \& Therapy 2013 15:R177.

\section{Submit your next manuscript to BioMed Central and take full advantage of:}

- Convenient online submission

- Thorough peer review

- No space constraints or color figure charges

- Immediate publication on acceptance

- Inclusion in PubMed, CAS, Scopus and Google Scholar

- Research which is freely available for redistribution

Submit your manuscript at www.biomedcentral.com/submit
Ciomed Central 